\title{
STRUCTURES CAUSED BY REPEATED FREEZING AND THAWING IN VARIOUS LOAMY SEDIMENTS: A COMPARISON OF ACTIVE, FOSSIL AND EXPERIMENTAL DATA
}

\author{
BRIGITTE VAN VLIET-LANOË AND JEAN-PIERRE COUTARD \\ Centre de Géomorphologie du C.N.R.S., Rue des Tilleuls, 14000 Caen, France \\ AND \\ ALBERT PISSART \\ Laboratoire de Géographie Physique et Géologie du Quaternaire, Université de Liège, 7 place du XX \\ Août, 4000 Liege, Belgique
}

\begin{abstract}
In this paper, the authors present the results of both macroscopic and microscopic investigations on structure development created by repeated ice lensing in various loamy experiments. Experimental data are compared with observations performed on active forms in High Arctic and Alpine Mountain environments. Those observations are also compared with phenomena observed in fossil periglacial formations of Western Europe.

Platy and short prismatic structure formation is bonded to the hydraulic and thermal conditions during ice segregation. When a long series of alternating freezing and thawing affects platy structures, the fabric evolves, also being influenced by slope and drainage conditions: cryoturbations, frostcreep, and gelifluction can appear. They are characterized by specific microfabrics which are better developed with an increasing number of cycles: this is clear in experiments where hydraulic and thermal parameters are better controlled.

Vesicles are also a prominent characteristic of the surface horizon in experiments and arctic soils. The genesis of vesicles is discussed on the basis of new observations and is related to the mechanical collapse of frost-created aggregates under the mechanical work of soil air escape during soil saturation by water at thaw.
\end{abstract}

KEY WORDS: Ice segregation Loamy textures Structural fabrics Experimental, active and fossil data Micromorphology Single ice lensing structure Sorted platy structure Frostcreep fabric Gelifluction fabric Cryoturbation Vesicles

\section{INTRODUCTION}

For ten years, frost experiments have been performed in both the Caen and Liège laboratories to investigate the structures of various loamy sediments as observed in fossil soils and sediments of Western Europe and to determine their palaeoclimatic significance. These textures are particularly frost susceptible and in massive sediment, it is rather easy to observe the structures created by ice segregation. Field and microscopic observations in High Arctic environments and in Alpine Mountains complete this work.

Usually, when a sediment with a minimum content of fines is affected by slow freezing, ice lensing occurs from the surface downwards with a rather regular pattern. In most of the cases, the ice lenses are wider spaced with depth in accordance with the lowering of the cooling rate and the progressive exploitation of the water reserve present in the sediment. Usually the lenses nucleate behind the freezing line (Williams and Wood, 1982). This feature occurs in non-saturated sediments by capillary feeding at the freezing plane created by a thermal gradient and the subsequent suction. A temporary break in the waterfilm and in its associated thermal contribution (latent heat of crystallization and soil heat transferred by water) favour a sudden displacement of the freezing plane deeper into the soil to more humid material, until the water/thermal equilibrium is restored.

In the experiments reported here, permafrost was not reconstructed; most of the hydraulic (drainage) and

0197-9337/84/060553-13\$01.30

(C) 1984 by John Wiley \& Sons, Ltd. 
thermal conditions used here were comparable to those occurring in cold temperate areas without permafrost, in the upper horizons of the active layer. In the different experiments from which results are reported here, the lowest temperature recorded reached $-7^{\circ} \mathrm{C}$; in the field, like in the winter 1982-83 in Northwestern Spitzbergen, temperature reached $-17^{\circ} \mathrm{C}$ at $20 \mathrm{~cm}$ of depth. Loams used in experimental works are extracted from different loess-like deposits from Belgium and Normandy. Observations were conducted in the same way in the field and in experiments, at both macroscopical and microscopical level. Macroscopical observations are performed following both microstratigraphical and pedological techniques. Vertical cuts are smoothed and polished with a sharp knife; structures are described from natural faces. All the observations are drawn in close details. Micromorphological observations are performed on thin section: the sample is slowly air dried (two months, woven in a soft paper to avoid shrinkage), and impregnated under vacuum with a polyester resin; sections are 40 to $30 \mu \mathrm{m}$ thick following the details to be observed. In so far as it is possible, the thin sections are described in language that can be understood by non-specialists.

\section{Single ice lensing}

To develop this type of formation, the material must undergo at least one but generally less than ten freeze-thaw cycles; in other words, it is produced by a small number of freeze-thaw cycles.

\section{Platy structure}

After melting of the segregated ice lenses, also called thaw consolidation, a platy structure is observed, as commonly described in the literature (e.g. Kokkonen, 1926; Taber, 1930; Pissart, 1970). Like the ice lenses themselves, the size of the platy aggregates (structure from a pedological viewpoint) is controlled by the thermal gradient, in other words by the depth and the water content. It ranges from a tenth of millimetre to several centimetres in thickness. In sediments on loamy sediments, structure development ranges from 'thinly bladed' $(0.5$ to $1.0 \mathrm{~mm}) 1-3 \mathrm{~cm}$ from the soil surface to 'fine platy' at $25 \mathrm{~cm}$ depth (2 to $4 \mathrm{~mm}$ in thickness).

Microscopically, platy aggregates are separated by smooth fissures, gently undulating and with unconformable walls, as a main contrast with desiccation cracks (Van Vliet-Lanoë, 1976). This unconformity of the walls is often associated with a 'gaping' character of the fissure (Figure 1). Ice segregation usually develops on a previous desiccation crack appearing below the freezing front (Beskow, 1935; Van Vliet-Lanoë, 1976) and smooths the roughness of its walls. Close to the soil surface, ice segregation is less intense than at depth and the fissure left by the ice after thawing at this level is very close to the shape of the desiccation cracks. The length/thickness ratio of the ice-created plates (Van Vliet-Lanoë, 1976) is generally close to 3 or lower, but in such a surface horizon, it can be a little higher. The bulk density of these aggregates, as seen in thin sections, is also less close to the surface (Figure 2) than at a greater depth, resulting in a more effective ice segregation. Those observations are very important in order to explain the relative low firmness of the frost-formed aggregates of the soil surface compared to their extreme firmness at depth.

During the experiments performed in Caen, the water content reached after thawing was only 20 per cent by volume. Here the platy aggregates were relatively close to those created by desiccation, with nearly complementary fissure walls. In contemporary lacustrine mud (silty loam) of a temporary lake (lac du Gouffre, La Mortice, southern French Alps), the water content by volume was after thawing higher than 30 per cent (thixotropic); the thickness of the aggregate was $2-3 \mathrm{~mm}$ at a depth of $10 \mathrm{~cm}$ which is similar to the experiments. A discontinuous fissure separating the aggregates is clearly visible, ranging from 0.1 to $0.5 \mathrm{~mm}$ in width. In a marine loamy clay (near Fort Chimo, Ungava Bay, Canada), the platy structure in a non-permafrost area ranges from thinly bladed close to the surface to coarse platy at a depth of $140 \mathrm{~cm}$; the discrete 'gaping' of the fissures ranges from 0.1 to $0.2 \mathrm{~mm}$ in well-drained sites and up to $1.0 \mathrm{~mm}$ in poorly-drained ones. In a close area (Ramah Bay, Canada) another glaciomarine loamy clay presents a well-developed platy structure at a depth of $60 \mathrm{~cm}$, just below the top of a permafrost. The discrete 'gaping' of the fissure has a width of $1.5 \mathrm{~mm}$ after slowly thawing the segregated ice (thermokarst) (Figure 1). The unconformity of the walls and the width of the fissure left by ice lensing is the expression of a local more accentuated growth of ice, as a result of an abundant water supply. It is in agreement with the drainage conditions and also with the possibility of water migration bonded to the texture at temperatures lower than $0^{\circ} \mathrm{C}$ (Burt and Williams, 1976) which may occur at temperatures as low as $-4^{\circ} \mathrm{C}$ in loams and $-20^{\circ} \mathrm{C}$ in loamy clays. These features can also be accentuated by the refreezing at 


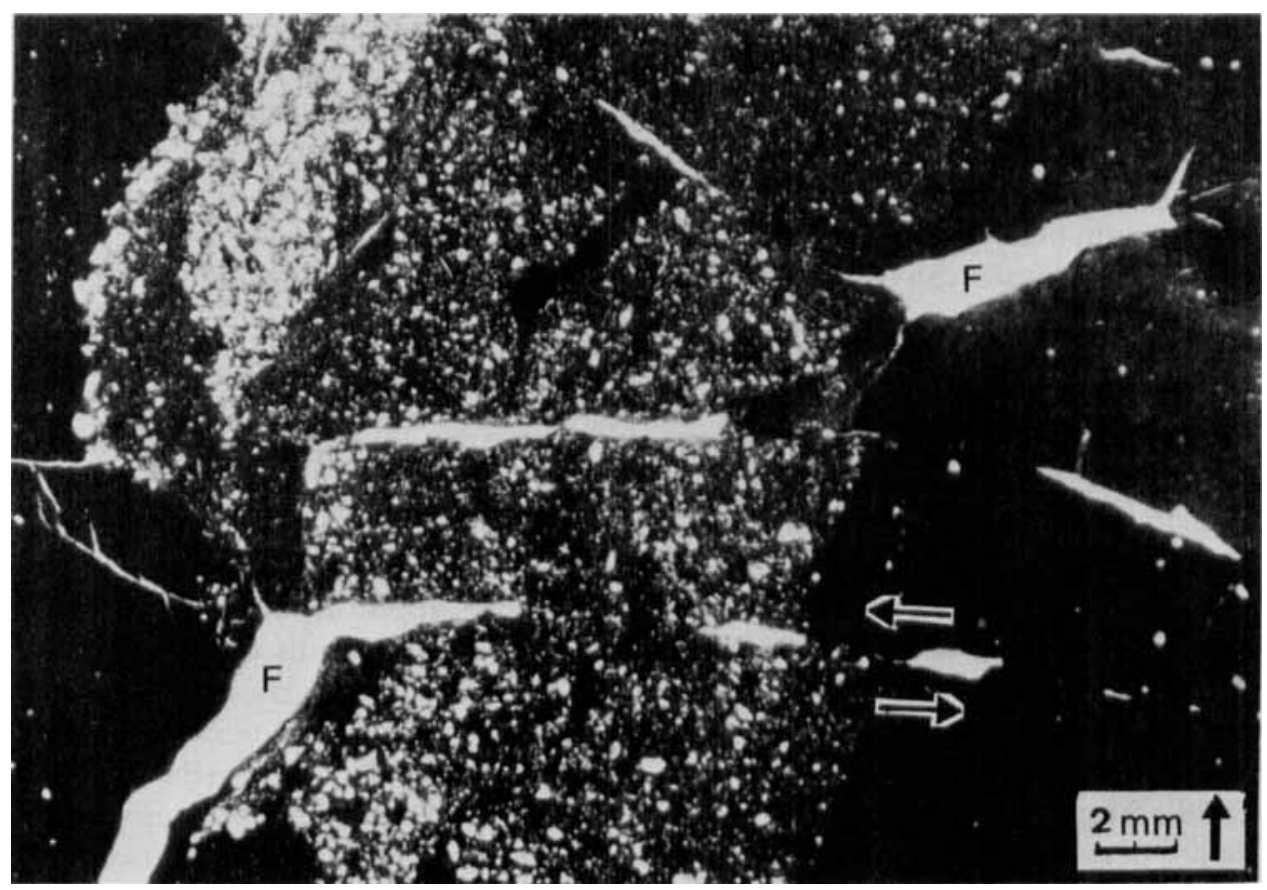

Figure 1. Traces of ice lenses in the top horizon of permafrost developed in a glaciomarine clay loam (Bay of Ramah, Labrador, Canada). The fissures left by the slowly thawed ice lenses are wide open (F). Notice the small lateral displacement (arrows) bonded to thaw settlement at the level of an older bioturbation (more sandy area)

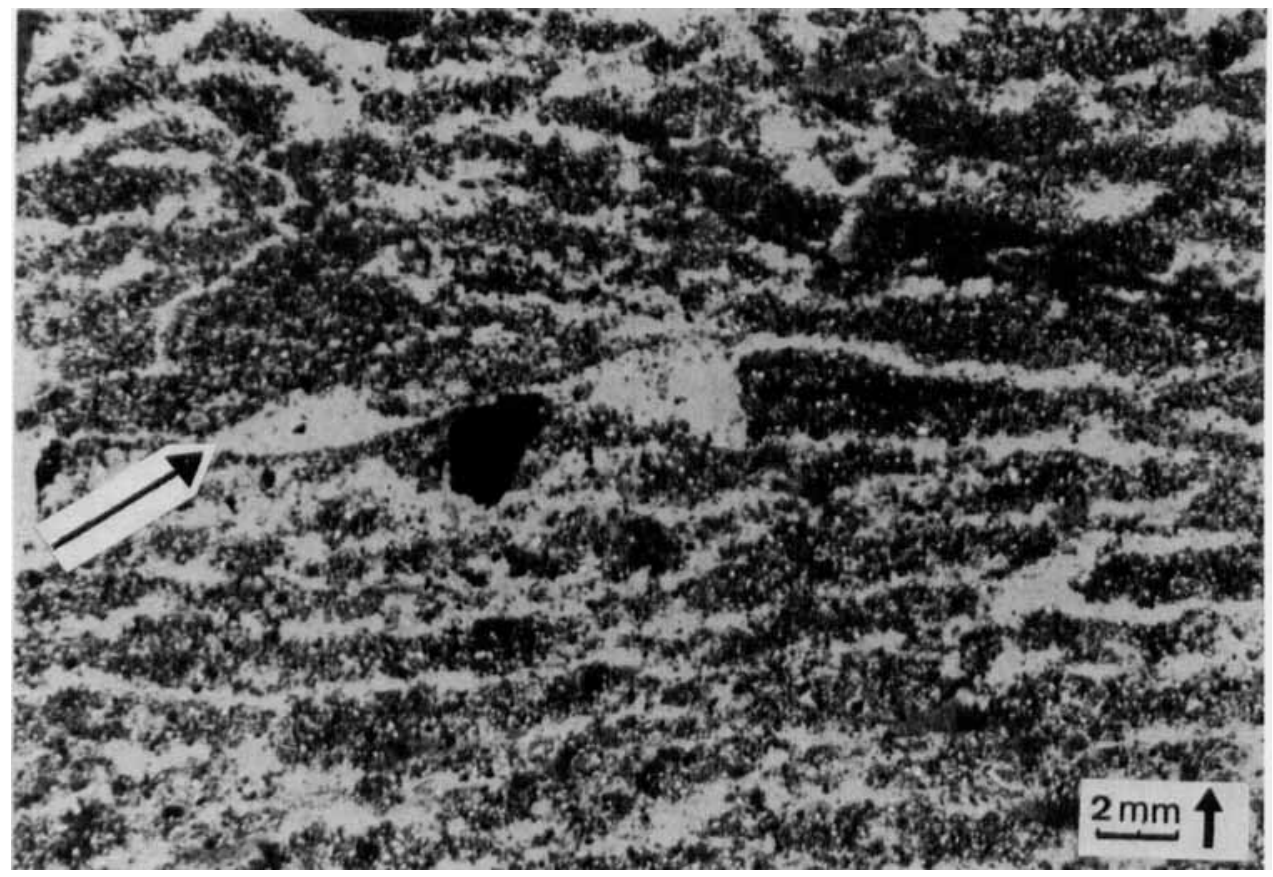

Figure 2. Frostcreep fabric produced experimentally in Caen after six cycles of alternating freezing and thawing. The interaggregate fissures are rather rough like desiccation cracks and the aggregates are weakly compacted. Notice the presence of a slipping plane associated with an incipient skeleton infilling (arrow) 
depth of thaw water as observed by Hoekstra (1969) in the top layer of permafrost, and by Mackay (1980) in hummocky soils.

Aggregates created in sediments by ice lensing are generally very stable because of their mechanical compaction (Van Vliet-Lanoë, 1976) and their ultradesiccation (Pissart, 1970; Journaux and Coutard, 1972). They are responsible for the characteristics of a 'periglacial' type of fragipan horizon which indicates a former permafrost top horizon (Van Vliet-Lanoë and Langohr, 1981a). In the field and in thin sections, small lateral displacements of the aggregates can be observed resulting in irregular settlement after the melting of the entire segregated ice (Figure 1).

\section{Short prismatic structure}

Another phenomenon directly related to ice segregation is the development of a short prismatic structure, which although not very frequent in nature is rather common in experiments. Subvertical fissures separate the aggregates. Usually, this structure appears when frost penetrates rapidly into the profile. Its normal location is at the base of the sample, just above the contact with the water supplying layer (Journaux and Coutard, 1972). This is the result of the occurrence of a small network of fissures appearing at the contact with the watersupplying layer when a break in the capillary rise, created by a textural discontinuity, produces a rapid exhaustion of the disposable water at the freezing plane. A volumetric reduction of the sediment follows. During experiments using pure loams and affected by this prismation, a water content of 12 per cent (wilting point) was measured above the textural discontinuity. This situation rapidly increases the thermal conductivity of the layer and the frost can penetrate quickly in to the dry sediment. The subvertical fissures which are straight or bayonet shaped in pure loam, are more irregular in coarse textured loams. The main network has a diameter of 10 to $15 \mathrm{~mm}$ over a length of 3 to $5 \mathrm{~cm}$. It is secondarily affected by ice segregation when the freezing plane goes deeper and the capillary feeding is restored. Ice blades occupy the fissures.

We have never observed this feature in fossil pure loams but it can be observed in stratified sandy 'heads' with a loamy matrix (Figure 3 ) or in some coarsely stratified fluvial deposits. In the field, we observed it also in small

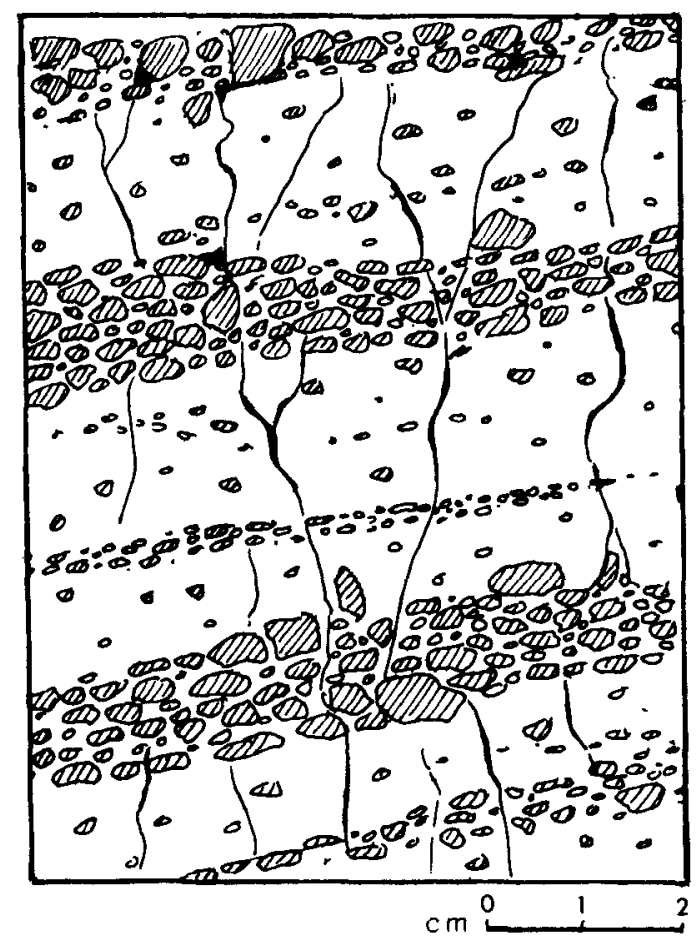

Figure 3. Short prismatic structure observed in stratified sandy heads (Cliff of Les Ilets, cap de la Hague, Western France). The white matrix is a sandy loam 
sorted polygons developed on a wind exposed site (calcareous loam) in Northwestern Spitzbergen (Figure 4) which is susceptible to drastic cooling. Here, the upper $7 \mathrm{~cm}$ of the soil is dominated by prismatic structure similar to those of the experiments. Below it, a fine platy structure normally develops. Such situations are, however, very common in poorly-drained clay loams, which give form to short prismatic structures likes those observed in varves in Scotland (Fitzpatrick, 1974) and in southern Finland, in some fragipan horizons (Van Vliet-Lanoë, 1980), and in active minerogenic palsas of northern Norway (Svenson, 1964) and Labrador (Gangloff and Pissart, in press). In clay loams, it is the result of the low hydraulic conductivity of massive sediments, especially when the initial water content is high. When it freezes, capillary water is very quickly crystallized though an important amount of bonded water still remains unfrozen (up to 25-30 per cent by volume). It means that at this first phase, bonded water continues to migrate very slowly, enhancing the previous segregated ice and the initial volumetric contraction.

\section{ALTERNATING FREEZING AND THAWING}

Several phenomena are related to long series of alternating freezing and thawing. Platy aggregates created by ice lensing evolve; we shall discuss it from three different view points.

\section{Freezing and thawing fabric}

When a long series of alternating freezing and thawing affects sediments, the aggregates evolve. If they are thin, they become lens shaped and a capping of fine particles (silt and clay) progressively covers the upper face of the aggregates. At the same time, a skeleton (Brewer, 1976) composed of clean and free mineral grains develops between the aggregates, forming a whitish loose coating of cryoexpelled grains. It usually shows a reverse graded bedding (Van Vliet-Lanoë, 1976); this is the reason why we call this type of fabric a sorted platy structure. The size of the aggregates is the same as in the former case (see Single ice lensing above) (Figure 5).

This type of structural fabric is well known to soil scientists working in boreal and low arctic environments (e.g. Dumanski, 1964; Fedorova and Yarilova, 1972; Bjorkhem and Jongerius, 1974). It is also frequently preserved in fossil periglacial deposits (e.g. Fitzpatrick, 1956, 1974; Romans and Robertson, 1974; Van VlietLanoë, 1976; Van Vliet-Lanoë and Flageollet, 1981). As this structural fabric has been fully described in a previous paper (Van Vliet-Lanoë, 1982), we shall not discuss its genesis here.

In experiments, Dumanski (1964) obtained a distinct freeze-thaw fabric in water-saturated conditions after 45 effective cycles (only a small volume of sediment was used). In the Caen and Liège experiments using drained
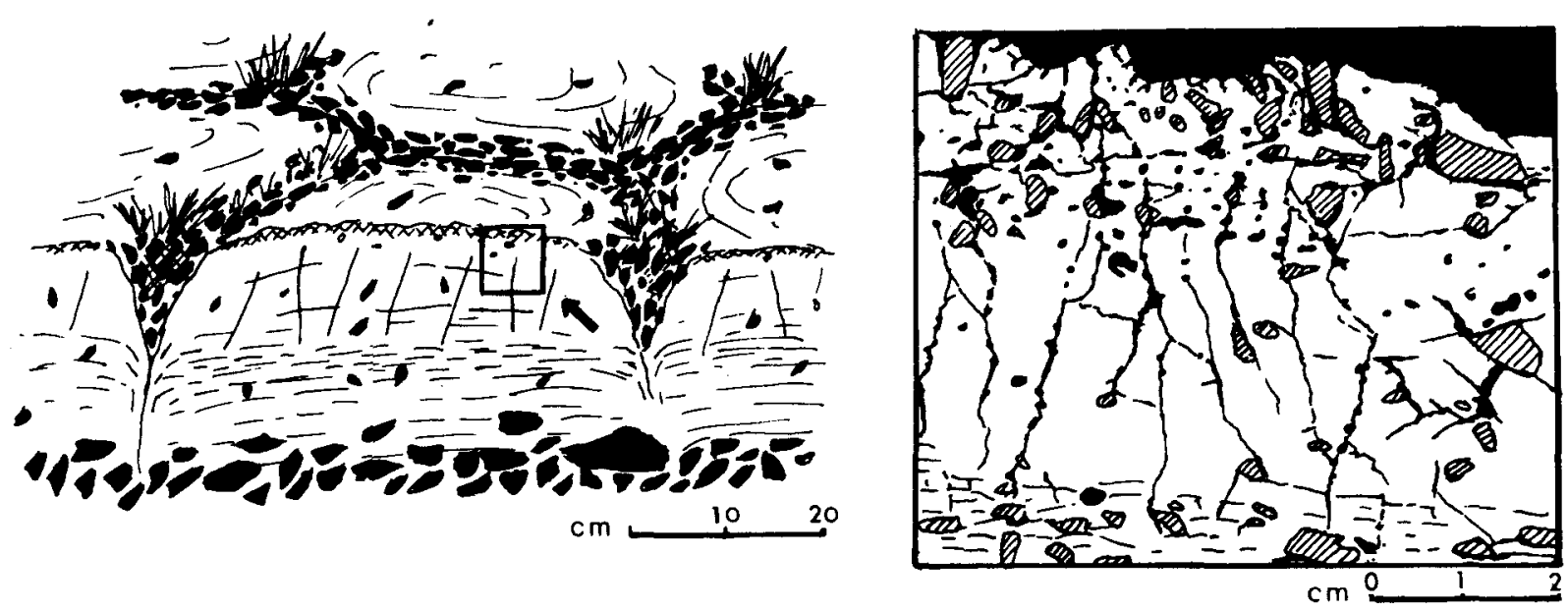

Figure 4. Short prismatic structure developed in small sorted polygons. Calcareous loam on a wind exposed site (French Camp, Ny Alesund, N. W. Spitzbergen). The prismatic structure dominates in the upper $7 \mathrm{~cm}$ and is progressively replaced in depth by a fine platy structure. Notice the presence of vesicles along the vertical fissure and in the surface layer 


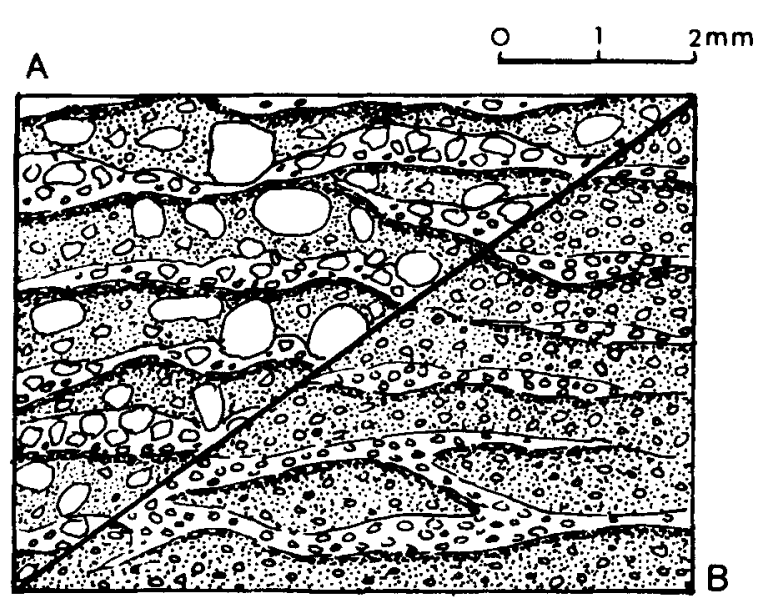

Figure 5. Freezing and thawing structural fabric, developed, on left (A) in a poorly-graded sandy loam, on right (B) in a well-graded loam

sediments (larger sized experiments), this structural fabric only became visible after 18 to 25 cycles. The silty cap in this case is very thin and discontinuous; only a few mineral grains are observed in the fissures.

In the field, as for example in the young sediments of Northwestern Spitzbergen (Van Vliet-Lanoë, 1983) this fabric needs many more cycles to be effective. To be discernable, it needs about 100 cycles; to be perfect, it needs more than 1000 . This means that in experimental conditions the cycles are at least three times more effective than in the field. This is the result of a more efficient thermal regime and an effectively continuous water supply during the experiments.

The expression of freeze-thaw structural fabric in sediments is also dependent on its grading and on its chemical and mineralogical composition (Van Vliet-Lanoë, 1976). In poorly-sorted glacial till or in colluvial sandy loam, it appears rather quickly and clearly. In contrast, well-graded loess or fluvial sands only develop faintly contrasted sorted fabric (Figure 5). In the well-graded laminated loam described in the companion paper by Coutard and Mücher (1984), it is practically not developed at all; in the same experiment, the poorlygraded loamy substratum did develop this fabric, though weakly expressed.

\section{Frostcreep and gelifluction}

If ice lensing produced by alternating freezing and thawing occurs in sediments affected by a gentle slope ( 2 to $17^{\circ}$ ), in early stages, the general fabric of the sediment remains identical to the previous one (see Freezing and thawing fabric above). The first features that occur in experiments after only six cycles, are subhorizontal shearings or slipping planes. In this case, the surface displacement reaches about $1 \mathrm{~cm}$ per cycle. These planes correspond to one of the fissures created by ice lensing. In thin sections, they are already associated with some sorted platy structure (with skeleton; Figure 2). It seems that it is always the same fissure which preferentially helps the slipping or shearing. This feature is associated with minute lateral displacements which appear during thawing (Figure 6) as observed in the surface horizon of a nearly stabilized solifluction lobe of Northwestern Spitzbergen. These observations confirm those of Williams in 1959 that the displacement is associated with ice lenses (see the discussion in the companion paper by Coutard and Mücher, 1984). Tilted shearing planes can also be generally observed when a lateral or frontal mechanical strain exists. It is rather frequent in experiments (see for example in the companion paper by Coutard and Mücher, 1984) but seldom occurs in the field excepted in small creeped unsorted polygons or in small 'terracettes' (Chandler, 1972).

When the number of cycles increases, the freeze-thaw fabric undergoes some deformation though the cap of fine particles and the skeleton remains clearly visible. If the sediment is sufficiently plastic, aggregates can be stretched and waved as in small sorted stripes in fine calcareous loams from Northwestern Spitzbergen (Figure 7). This is also observed in experiments (see Coutard and Mücher, 1984). In contrast, if the aggregates are coarser and less plastic, they become rounded and the cap dissymetric in the slope direction (Van Vliet-Lanoë, 1982). This is commonly observed in the field in fossil and active forms (Romans and Robertson, 1974; Harris, 


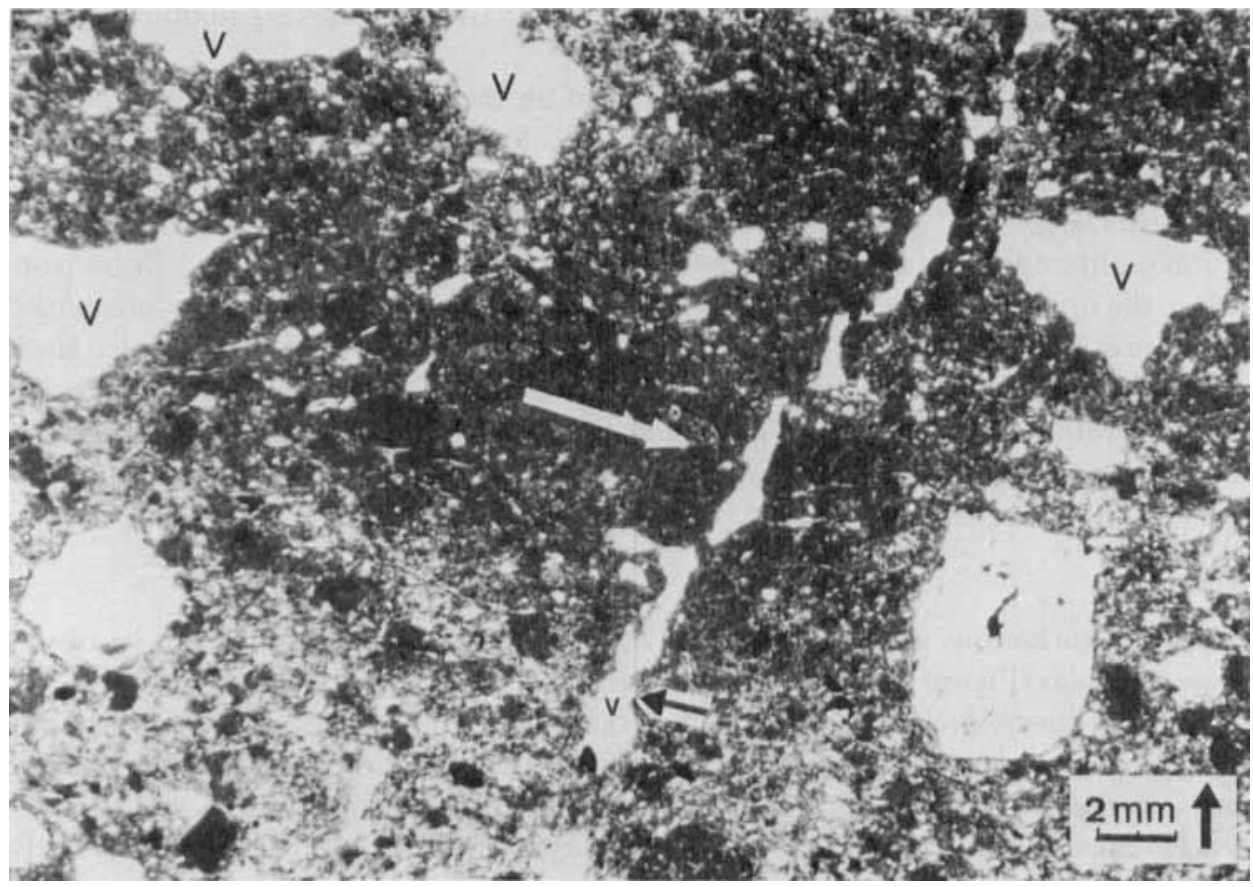

Figure 6. Frostcreep fabric in the surface horizon of a sandy clay loam; nearly stabilized solifluction lobe in the Mindre Lovenbreen morainic arc, Ny Alesund, Northwestern Spitzbergen. During the last thawing, a vertical fissure has been exploited by as an air leakage and somewhat affected by structural collapse (black arrow). Slipping planes corresponding to former ice lenses produce an horizontal sectioning and a lateral shift of the fissure in the slope direction (white arrow). Notice also the presence of mammillated vesicles resulting in incomplete structural collapse (V)

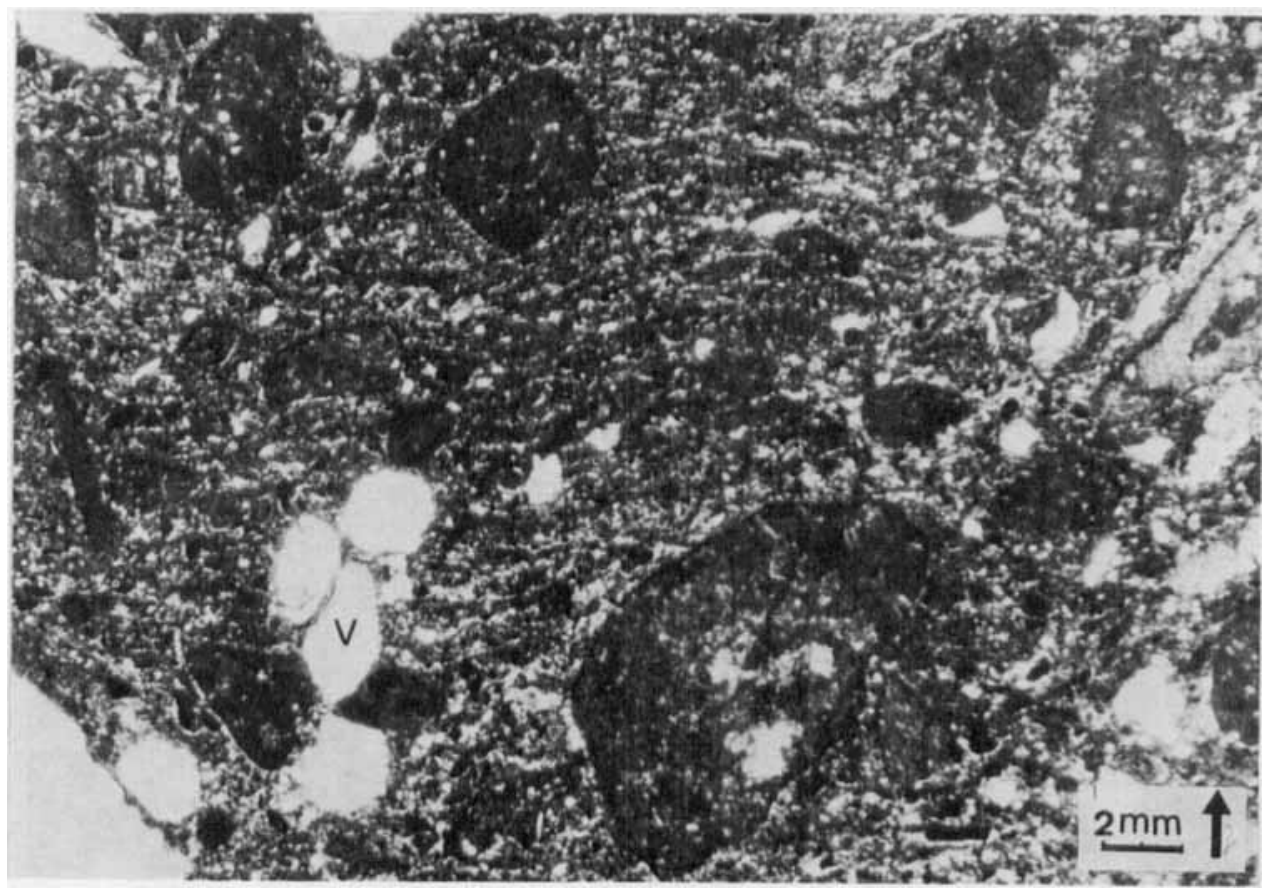

Figure 7. Frostcreep fabric in a stony calcareous loam; microstripes on a $7^{\circ}$ slope (French Camp, Ny Alesund, Northwestern Spitzbergen). The plastic properties of the loam allows wavy deformations of the sorted platy structure produced by repeated ice lensing as a result of soil creep at thaw. Notice the presence of vesicles (V) 
1981; Van Vliet-Lanoë and Valadas, 1983; Van Vliet-Lanoë, 1983) in slow moving solifluction lobes, but it has not yet been reproduced in the laboratory.

If the speed of displacement still increases, resulting of an increasing slope or water inflow, gelifluction occurs. It is characterized by well rounded aggregates with a silty cap on several faces, attesting to a rotation of the material (Van Vliet-Lanoë, 1982), when the sediment is temporarily supersaturated. It is associated with surface displacements larger than $10 \mathrm{~cm}$ per cycle. They are well known in fossil formations (Van Vliet-Lanoë and Valadas, 1983) although frequently confused with cryoturbations (Romans and Robertson, 1974) and where observed in the upper horizons of gelifluction lobes of Northwestern Spitzbergen, creeping down about $50 \mathrm{~cm}$ a year (Figure 8, Van Vliet-Lanoë, 1983). This has yet to be reproduced experimentally. In contrast with cryoturbation, bioturbation, or colluviation, the gelifluction granular fabric presents a well-developed silty to clayish cap and free grains occur between the peds (non-sorted skeleton). In well-expressed fabric, the silty cap shows distinct layering, a main difference with shear and biological granular aggregate. This type of fabric is also constant throughout the layer, also in contrast with cryoturbation.

\section{Cryoturbations}

Two main types of turbations associated with alternating freezing and thawing can be observed.

Vertical stones or grains (Figure 9). This mechanism is well known macroscopically (Beskow, 1935; Pissart, 1966, 1982); like those forms previously discussed, it occurs from a millimetric scale to a metric one. It is common in the field and can be reproduced easily. For fragments $5 \mathrm{~mm}$ long, a dozen cycles may be enough to reach a vertical orientation. In thin section, these fragments are often associated with granular or platy aggregates. A wide open pore, accentuated by ice lensing, is usually preserved at their base. It also occurs in periglacial formations developed on horizontal surfaces and in slope deposits.

Injections features. These are frequent in both fossil (Figure 10) and active soils (Figure 11) exploiting every kind of vertical and tilted fissures: desiccation network, interprismatic fissures (see Short prismatic structures above), and shearing planes. In the companion paper by Coutard and Mücher (1984), they were reproduced

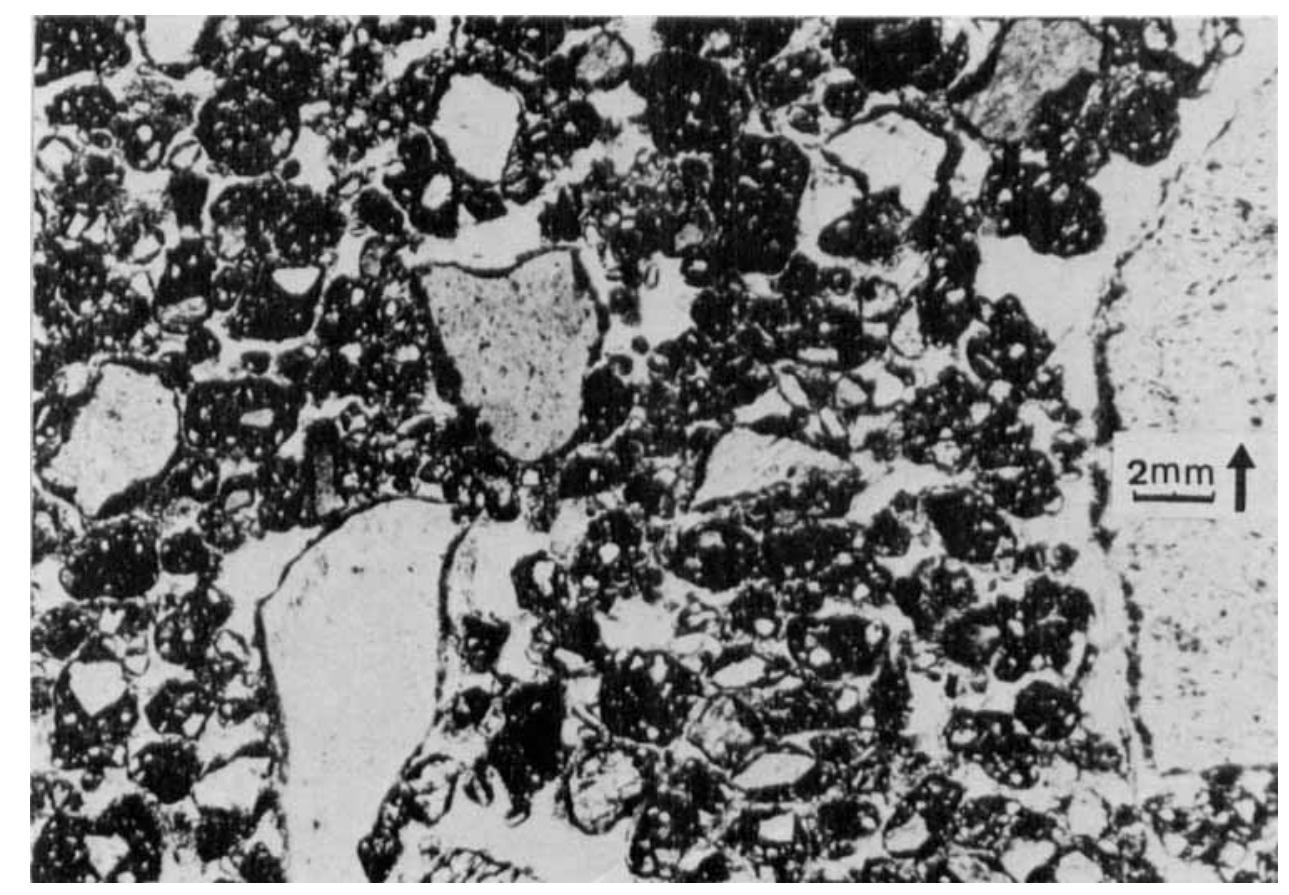

Figure 8. Gelifluction fabric in a stony sandy loam; surface horizon of an active gelifluction lobe (Autre Lovenbreen morainic arc, Ny Alesund, Northwestern Spitzberg). The aggregates are rounded and covered on all the faces by a silty cap, well visible on the sand grains and gravel sized particles 


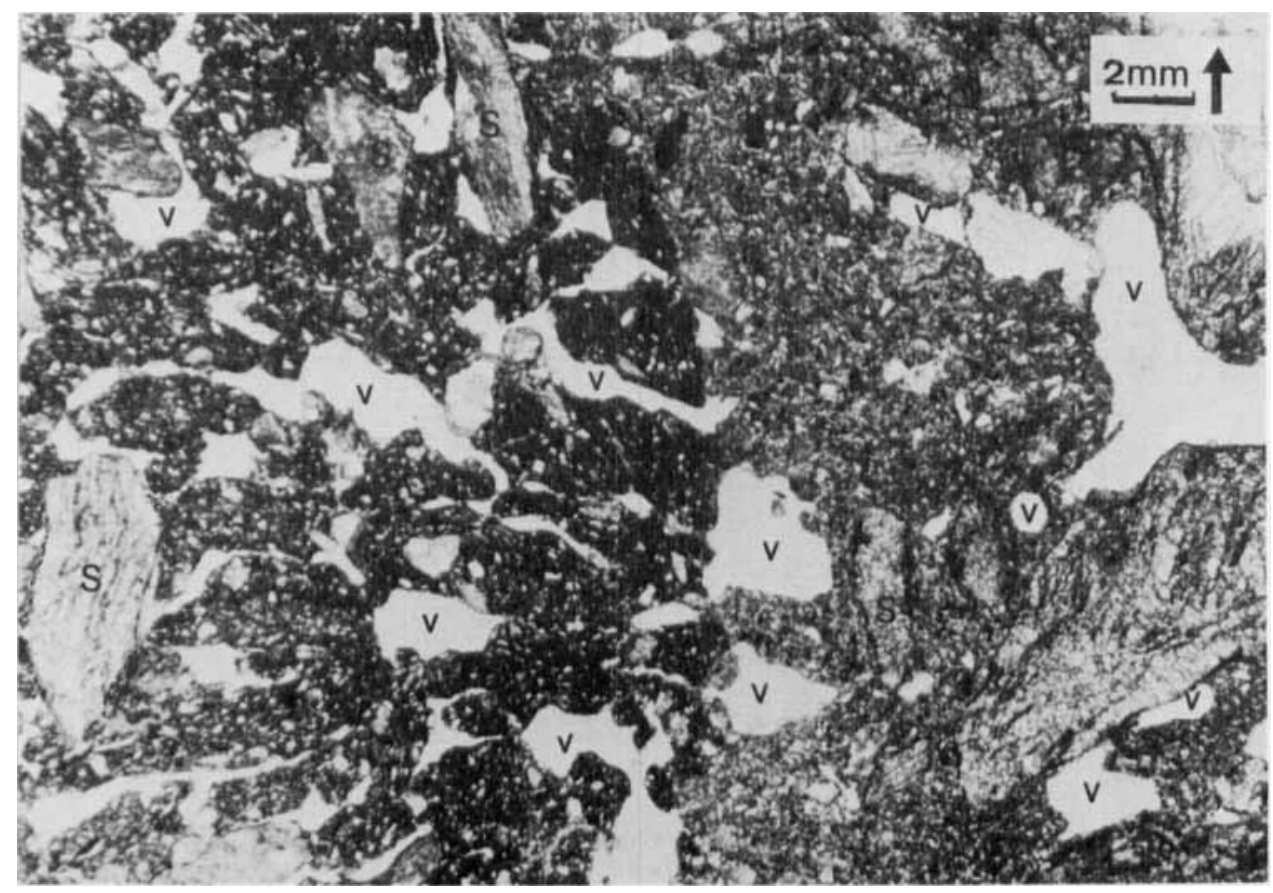

Figure 9. Field experiment in small sorted polygons (Chambeyron, Southern French Alps). The thixotropic clacareous stony loam has been admixt on the left side of the picture with a blue dye acting like a structural stabilizing agent. On the right side of the picture the normal sediment presents smooth and rounded vesicles (V); on the left, vesicles are irregular to mammillated, revealing an incomplete collapse of the ice-created aggregates. Notice vertical shale fragments (S), already visible in the 'blue' sediment

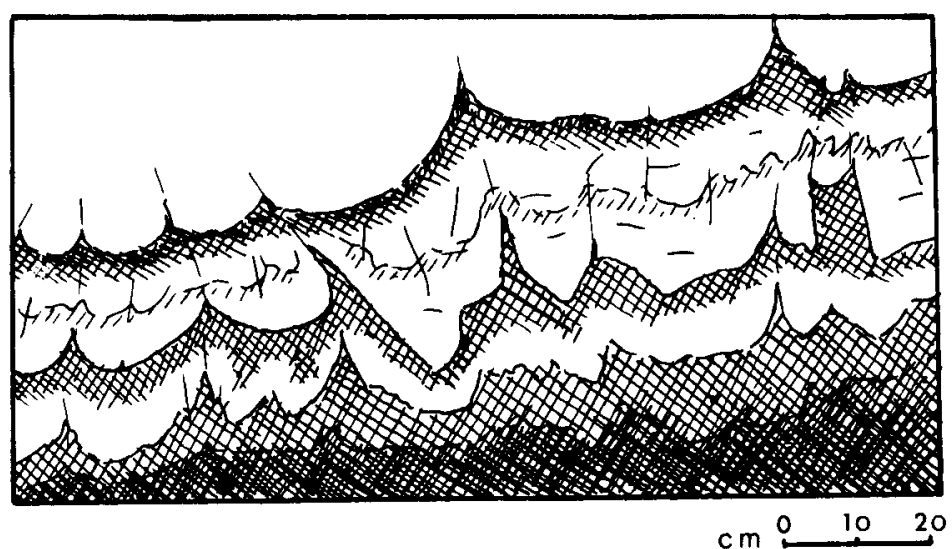

Figure 10. Injection features observed in the peaty layers of a fossil palsa (Konnersvenn, Belgian Ardennes). The injections of the peat follow short prismatic structure and some shearing planes (tilted in the slope direction)

experimentally at the level of the shearing planes. The microscopic observation of the injected material shows that at thawing, no liquefaction exists excepted in loose sands; usually injected material shows a new platy structure if it is rather thixotropic (Van Vliet-Lanoë, 1983); if it is plastic, the aggregates become granular. As injections seem to be rather quickly formed, the capping and the skeleton created by repeated freezing and thawing are generally not developed. Granular structure is restricted to specific zones in the profile where lateral strain resulting from differential heave are susceptible to deform plastic platy aggregates. The size of the aggregates depends also on the thermal gradient as in the former cases (see Single ice lensing and Freezing and 


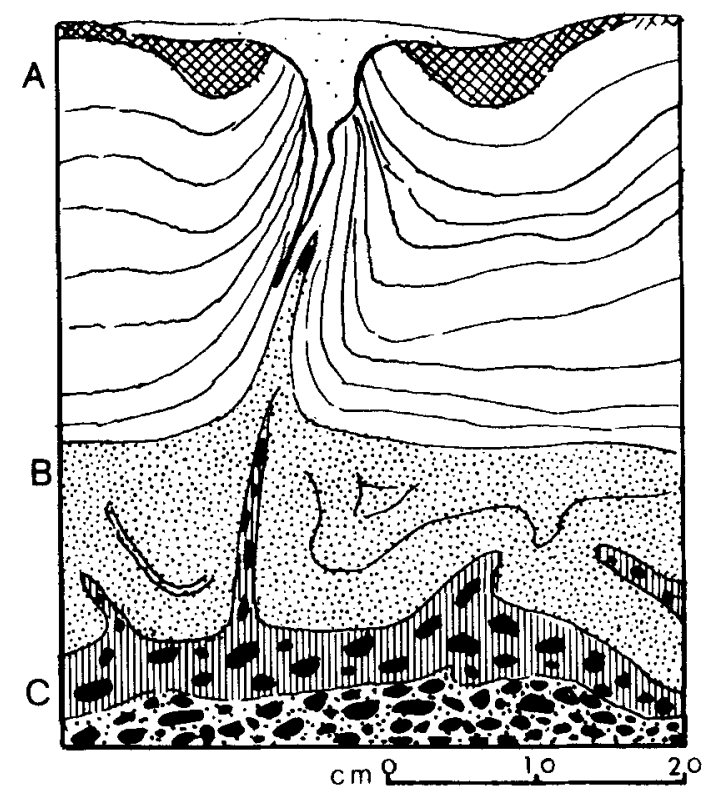

Figure 11. Injection feature observed in colian sand. (A) near Gåsbu, Ny Alesund, N. W. Spitzbergen, (B) marine sand, (C) humic silty accumulation on permafrost. It is associated with drying cracks and thermal cracks. The result is a regular cryoturbation pattern

thawing fabric above). Those features resulting from differential frost heaving are controlled by local textural variations (Sharp, 1942) and are able to initiate periglacial involutions (Van Vliet-Lanoë and Coutard, in press).

\section{VESICLES}

In arctic soils, vesicles are a prominent characteristic of the surface horizons developed in various loamy textures. They are common in a wide range of soils from tropical deserts to arctic environments. In tropical soils, in desert soils, in paddy soils, and in other crop soils, they are generally the result of soil aggregates which have collapsed under splash effect and upon wetting (Volk and Geyger, 1970; Miller, 1971; De Ploey and Mücher, 1981). A different hypothesis was used to explain their peculiar abundance in the Arctic. In 1956, Fitzpatrick proposed that it was the result of air expelled from soil water during freezing. This theory has been

1 by most of authors since then (Chandler, 1972; Bunting, 1977; Harris and Ellis, 1980). On another hand sucording to Brewer (1976), vesicles are the result of the growing ice lenses during the freezing of the soil surface. But from our observations, in the field or during experiments (observations of frozen cores or frozen lumps) vesicles do not exist before the first thawing of material freshly exposed to frost, except if they are synsedimentary as described in the companion paper of De Ploey and Mücher (1984). Air trapped in ice crystals exist but in such small amounts that it can not explain the high volume of air contained in the vesicles.

In natural exposures, vesicles are very common, generally in the upper 5 to $10 \mathrm{~cm}$ of the soil, as well as in polygons and gelifluction lobes (Van Vliet-Lanoë, 1983). They are especially well developed in small depressions or below snow patches where soils are likely to be supersaturated with water when thawing occurs. Vesicles exist in all frost-susceptible material. In some cases, like in the material overlying a watertable, it can occur in lower horizons; Bunting (1977) described them in the inner horizons of a non-sorted polygon (mudboil), which usually is characterized by highly thixotropic material. Their size is regularly larger than in experiments, where especially in the finest textured sediments, lengths sometimes reach up to $2-3 \mathrm{~cm}$ (tubular forms). In experiments, vesicles are very common, also in the top $5 \mathrm{~cm}$ below the surface corresponding also with the quickest frozen material, usually frost dried before thawing. In fossil material, vesicles can be preserved as isolated exemplar or 'foamy' layers in non-calcareous material, commonly associated with 
frostcreep or gelifluction fabric. In calcareous sediments, they can be fossilized in the same conditions as small microgeodes of calcite (Van Vliet-Lanoë, 1976).

The observation of the shape of the vesicles is very important. In highly thixotropic textures, they are well rounded and smooth (Plate 6, right side) whereas in clayish textures, they are mammillated (Plate 3). In a field experiment performed by Pissart (Chambeyron, Southern French Alps) the same texture reacted differently when mixed with a stabilizing agent (blue dye). Well rounded without dye, the vesicles become clearly mammillated in its presence and reveal an incomplete collapse of the ice-created platy aggregates (Plate 6). This feature clearly shows that the vesicles result from air expulsion confined by the structural collapse that occurs during the thawing. The reason for this is that during ice segregation, the soil aggregates are dried (ice $\mathrm{pF}: 6 \cdot 2$ ) and air contained in the sediment, between the ice lenses and also between the ice crystals. In the main case, when the thawing starts from the surface, the melting water confines the soil air in depth which has to be expelled. Air bubbles try to escape and have to overcome the hydrostatic pressure and the high viscosity of cold water, which is three times higher than at $20^{\circ} \mathrm{C}$. This means that the size of the air bubbles and the energy needed to reach the waterfree surface are much more destructive concerning soil aggregates than in temperate to warm conditions. The thawing produces an intense bubbling at the surface of the soupy soil which is easily visible during loamy experiments. The destructive action of bubbling is more efficient if the ice content is high and the thawing is quick.

As we have previously seen, the aggregates located close to the surface are not strongly compacted. Following the law of Poiseuille, the theoretical stability of aggregates is very good in cold water, but nevertheless the high dielectric properties of melt water can also oppose to this phenomenon. Harris and Ellis (1980) noticed that 'at a depth in excess of $25 \mathrm{~cm}$, overburden pressure appears to cause collapse of the vesicles'. But as another application of the Poiseuille law, well-compacted aggregates like those occurring at this depth are a thousand times more stable than those occurring close to the surface (square of the radius of the main porosity). In fact, wide open fissures (see Single ice lensing above) are extremely stable; they remain in soils for millenia! Because of this, some authors like Bunting (1977) confused pores left by intense ice lensing, for example at the base of a stone, with a collapsed vesicle. In contrast, during experiments, bubbling occurred in upright desiccation cracks (Figure 12) as evidenced by vertical cracks along which are escapes to the surface; a local superficial collapse of the aggregate is visible along the crack (Figure 2 and Plate 3), the sharp edges of the fissure being blunted. Moreover, it seems that similar to what is occurring with alternating wetting and drying (Figuera and Stoops, 1983) vesicles once formed are re-used and sometimes keep growing. This could explain centimetric forms. When buried, a former surface horizon conserves its vesicles, cut again but new ice lenses. In experiments, ice crystals are frequently observed in vesicles (Journaux and Coutard, 1972).

The effect of a long and aggressive mechanical work of bubbling and a weaker aggregate stability close to the surface of frost-susceptible soils explain fairly well the abundance of vesicles as observed in freezing and thawing soils, both in experiments and in the field. Nevertheless, when they occur alone, they do not have any palaeoclimatic significance.

\section{CONCLUSIONS}

Phenomena occurring under alternating freezing and thawing are created by ice lensing and by the strains related to the frost heaving. They cover a wide range of structural fabrics from single platy to granular structures in the case of cryoturbations, or to short prismatic structures in case of temporary desiccation. If a slope exists, at thaw, the lateral sliding sheet by sheet of the platy aggregates in the downstream direction produces a progressive deformation of the peds to frostcreep and to gelifluction fabric.

Most of these structures occurring in nature are reproducible by experiments. Only evolved frostcreep or gelifluction fabrics have not yet been reproduced because of the high number of cycles needed to obtain welldeveloped features. Experiments are much more effective than nature as a sequence of better controlled thermal and hydraulic parameters is possible.

All these structures are indelible once formed, except in case of strongly active biological mulching. They are of great interest as well to explain the internal dynamics of periglacial forms like cryoturbations and to understand the inheritances existing in surface soils or the diagenetic features affecting palaeosoils in present 


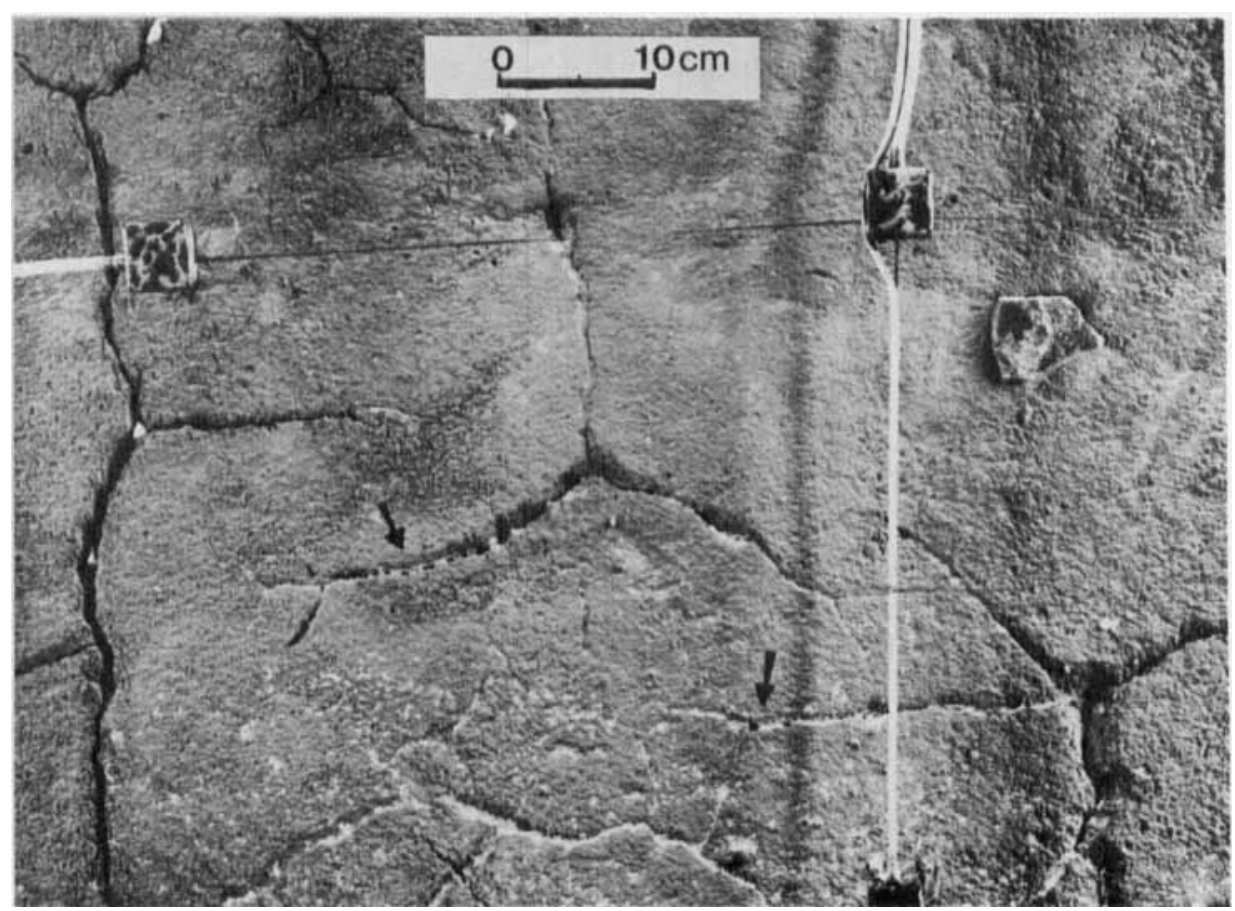

Figure 12. Surface of a large experimental model, performed in Caen. The surface of the silty loam affected by repeated freezing and thawing presents a well-developed desiccation network along which air escapes to the surface during thaw. Vesicles are visible in the cracks (arrows)

temperate to cold temperate environments. The platy aggregates or short prismatic with sorted skeletons are commonly observed in temperate soils. Correlating this with palynological or morphological obervations at a regional scale, we are able to attribute these fabrics to colder events occurring for example in Late Tardiglacial time and, in this way, to attribute certain pedological features to either older or more recent climatic phases (Van Vliet-Lanoë and Langohr, 1981b).

Climatic meaning of these fabrics depends on their depth of occurrence and of the structural pattern in the profile. Most of these are only indicators of seasonal frost (Van Vliet-Lanoë, 1984).

\section{ACKNOWLEDGEMENTS}

We would like to express our thanks to Douglas Fisher for correcting our translation and suggesting ways of improving our original text.

\section{REFERENCES}

Beskow, G. 1935. 'Tjälbildningen och tjällyftningen', Sverige Geologiska Undersökingen, C26, (3), Reprot n`375, 242 pp. Bjorkhem, H. and Jongerius, U. 1974. 'Micromorphological observations in some podzolized soils in Central Sweden', in Rutherford, G. K. (Ed.), Soil Microscopy. Proceedings of the 4 th International Working Meeting on Soil Micromorphology, Kingston, Ontario, Canada, 320-332.

Brewer, R. 1976. Fabric and Mineral Analysis of Soils, Krieger R. E. Publishing Company, Huntington, New York, 482 pp.

Bunting, B. 1977. 'The occurrence of vesicular structures in arctic and sub-arctic soils', Zeitschrift für Geomorphologie, 21, 89-95.

Burt, T. P. and Williams, P. J. 1976. 'Hydraulic conductivity in frozen soils', Earth Surface Processes and Landforms, 1, (4), 349-360.

Chandler, R. 1972. 'Periglacial mudslides in West Spitzbergen and their bearings on the origin of fossil solifluction shears in low angled clay slopes', Quarterly Journal of Engineering Geology, 5, 223-241.

Coutard, J. P. and Mücher, H. M. 1984. 'Deformation of laminated silt loam due to repeated freezing and thawing', Earth Surface Processes and Landforms.

De Ploey, J. and Mücher, H. M. 1981. 'A consistency index and rainwash mechanisms on Belgian loamy soils', Earth Surface Processes and Landforms, 6, 319-330. 
Dumanski, J. 1964. A Micropedological Study of Eluviated Horizons, Master Thesis, University of Saskatchewan, unpublished, $124 \mathrm{pp}$

Fedorova, N. N. and Yarilova, E. A. 1972. 'Morphology and genesis of seasonally frozen soils in Western Siberia', Geoderma, 7, 1-13.

Figuera, H. and Stoops, G. 1983. 'Application of micromorphometric techniques to the experimental study of vesicular layer formation', Pédologie, 33, (1), 77-89.

Fitzpatrick, E. A. 1956. 'An indurated soil horizon formed by permafrost', Journal of Soil Sciences, 7, 1-13.

Fitzpatrick, E. A. 1974 'Cryons and Isons', Proceedings of the North England Soil Discussion Group Penrith, 11, $31-43$.

Gangloff, P. and Pissart, A in press. 'Evolution géomorphologique et palses minérales près de Kuujjuaq (Fort Chimo, Québec)', Bulletin de la Société Géographique de Liège.

Harris, C. and Ellis, S. 1980. 'Micromorphology of soils in soliflucted materials, Okstindan, Northern Norway', Geoderma, 23, 11-29.

Harris, C. 1981. 'Microstructure in solifluction sediments from South Wales and North Norway', Biuletyn Peryglacjalny, (28), $221-226$.

Hoekstra, P. 1969. 'Water movement and freezing pressures', Soil Sciences Society of America, Proceedings, 33, 512-518.

Journaux, A. and Coutard, J. P. 1972. 'Etude en similation de l'action du gel sur de grands modèles de sols', Bulletin du Centre de Géomorphologie du C.N.R.S., (13-14-15), 35-62.

Kokkonen, P. 1926. 'Beobachtungen über die Struktur des Bondenfrostes', Acta Forestalia Fennica, 30, 1-55.

Mackay, R. 1980. 'The origin of hummocks, Western Arctic Coast, Canada', Canadian Journal of Earth Sciences, 17, 996-1006.

Miller, D. E. 1971. 'Formation of vesicular structure in soils', Soil Sciences Society of America, Proceedings, 35, 635-643.

Pissart, A. 1966. 'Expériences et observations à propos de la génèse des sols polygonaux triés', Revue Belge de Géographie., 90, (1), 55-73.

Pissart, A. 1970. 'Les phénomènes physiques essentiels liés au gel, les structures périglaciaires qui en résultent et leur signification climatique', Annales de la Société Géologique de Belgique, 93, 7-49.

Pissart, A. 1982. 'Deformations de cylindres de limon entourés de graviers sous l'alternance de gel-dégel', Biuletyn Peryglacjalny, (29), $275-285$.

Romans, J. and Robertson, L. 1974. 'Some aspects of the genesis of alpine and upland soils in the British Isles', in Rutherford, G. K. (Ed.), Soil Microscopy. Proceedings of the 4th International Working Meeting on Soil Micromorphology, Kingston, Ontario, Canada, 498-510.

Sharp, R. P. 1942. 'Periglacial involutions in Illinois', Journal of Geology, 50, 113-133.

Svenson, H. 1964. 'Structural observations on the minerogenic core of a pals', Svensk Geografiska Arbok, 40, $138-142$.

Taber, S. 1930. 'The mechanics of frost heaving', Journal of Geology, 38, 303-317.

Van Vliet-Lanoë, B. 1976. 'Traces de ségrégation de glace en lentilles associées aux sols et phénomènes périglaciaires fossiles', Biuletyn Peryglacjalny, (26), 41-54.

Van Vliet-Lanoë, B. 1980. 'Corrélation entre fragipan et permagel. Application aux sols lessivés glossiques', Régionalisation du Périglaciaire, Notes et Comptes-rendus, Strasbourg, (5), 9-22.

Van Vliet-Lanoë, B. 1982.'Structures et microstructures associées à la formation de glace de ségrégation; leur conséquences', in French, H. (Ed.), The Roger Brown Mémorial. Proceedings of the 4th Canadian Permafrost Conference, Calgary, Alberta, March 1981, National Research Council Canada, 116-122.

Van Vliet-Lanoë, B. 1983. Etudes Cryopédologiques au Sud du Kongsfjord, Rapport de las Misson Spitzberg 1982, Publication interne du Centre de Géomorphologie du C.N.R.S., 40 pp.

Van Vliet-Lanoë, B. in press. 'Frost effects in soils. Inheritances and applications', in Boardman, J. (Ed.), Soils and Landscape Evolution, Wiley \& Sons, $38 \mathrm{pp}$.

Van Vliet-Lanoë, B. and Flageollet, J. C. 1981. 'Traces d'activité périglaciaire dans les Vosges Moyennes', Biuletyn Peryglacjalny, (28), 208-216.

Van Vliet-Lanoë, B. and Langohr, R. 1981a. 'Correlation between fragipan and permafrost with special reference to silty Weichselian deposits in Belgium and Northern France', Catena, 8, 137-154.

Van Vliet-Lanoë, B. and Langohr, R. 1981b. 'Evidence of disturbance by frost of pore ferriargilans in silty soils of Belgium and Northern France', in Bullock, P. and Murphy, C. (Eds), Soil Micromorphology. Proceedings of the 6th International Working Meeting on Soil Micromorphology, London, 511-518.

Van Vliet-Lanoë, B. and Valadas, B. 1983. 'A propos des formations déplacées de versants cristallins des massifs anciens: le rôle de la glace de ségrégation dans la dynamique', Bulletin de l'Association Française pour l'Etude du Quaternaire, (4), 153-160.

Van Vliet-Lanoë, B. and Coutard, J. P. in press. 'II-Genèse de sols cryoturbés en gouttes par gonflement cryogénique différentiel', in Lautridou, J. P., Ozouf, J. C., Van Vliet-Lanoë, B., and Coutard, J. P. (Eds), A propos de Deux Thèmes de Recherche Abordés au Centre de Géomorphologie du C.N.R.S.. Biuletyn Peryglacjalny, special volume (30) in honour of A. Dylikowa.

Volk, O. H. and Geyger, E. 1970. 'Schaümböden als Ursache der Vegetations Losigkeit in ariden Gebieten', Zeit schrift für Geomorphologië, 14, (1), 79-95.

Williams, P. J. and Wood, J. A. 1982. Investigations of Moisture Movements and Stresses in Frozen Soils, Final Report of the Geotechnical Sciences Laboratories, Carleton University, Ottawa, Contract serie $n^{\circ}$ OSV81-00119, $100 \mathrm{pp}$. 